\title{
Perkembangan Bioteknologi di Indonesia
}

\author{
Ummi Wasilah, Siti Rohimah, Mukhamad Su'udi* \\ Jurusan Biologi, Fakultas Matematika dan Ilmu Pengetahuan Alam, Universitas Jember \\ *msuudi.rda@gmail.com
}

DOI: https://doi.org/10.21107/rekayasa.v12i2.5469

\begin{abstract}
ABSTRAK
Bioteknologi telah berkembang di Indonesia sejak lama namun cenderung lambat dikarenakan oleh beberapa faktor. Faktor pertama adalah minimnya dana penelitian dalam bidang bioteknologi. Penelitian bioteknologi dibutuhkan untuk meningkatkan kuantitas dan kualitas produk serta pengetahuan tentang bioteknologi. Faktor lain yaitu rendahnya sumber daya manusia, fasilitas dan kebijakan pemerintah yang terkesan memperpanjang proses pemasaran produk rekayasa genetika. Bioteknologi memiliki peranan positif bagi dunia pertanian, kesehatan serta lingkungan. Dalam dunia pertanian, bioteknologi membantu untuk mengurangi krisis pangan, memperbaiki kualitas pangan dan meningkatkan jumlah produksi hasil pertanian. Di bidang kesehatan, bioteknologi dapat mendiagnosis suatu penyakit genetis maupun non genetis serta mengobati penyakit tertentu. Dalam bidang lingkungan, bioteknologi dapat meningkatkan kualitas lingkungan yang telah tercemar seperti remediasi, bioleaching, mengurangi sampah plastik dengan memproduksi bioplastik serta memproduksi pupuk hayati yang ramah lingkungan.
\end{abstract}

Kata Kunci: bioteknologi, faktor, pertanian, kesehatan, lingkungan

\section{Development of Biotechnology in Indonesia}

\section{ABSTRACT}

Biotechnology has developed in Indonesia for a long time but tends to be slow due to several factors. The first factor is the lack of research funding in the field of biotechnology. Biotechnology research is needed to increase the quantity and quality of products and knowledge about biotechnology. Other factors are low human resources, facilities, and government policies that seem to extend the marketing process of genetic engineering products. Biotechnology has a positive role for the world of agriculture, health and the environment. In the world of agriculture, biotechnology helps to reduce the food crisis, improve food quality and increase the amount of agricultural production. In the health sector, biotechnology can diagnose a genetic and non-genetic disease and treat certain diseases. In the environmental field, biotechnology can improve the quality of polluted environments such as remediation, bioleaching, reducing plastic waste by producing bioplastics and producing environmentally friendly biological fertilizers.

Keywords: biotechnology, factors, agriculture, health, environment

\section{PENDAHULUAN}

Bioteknologi di Indonesia telah berkembang sejak lama, misalnya pembuatan keju, tempe, oncom dan lain sebagainya. Namun bioteknologi modern baru berkembang pada tahun 1985 ketika Menteri Pendidikan dan Kebudayaan yang mengizinkan munculnya program Bioteknologi seperti Bioteknologi pertanian IPB, Bioteknologi kesehatan di UGM dan Bioteknologi Industri di ITB Bandung. Tujuan pemerintah dalam program ini adalah untuk meningkatkan penelitian di bidang bioteknologi dan memperluas jaringan bioteknologi di tingkat nasional maupun internasional (Wahyono, 2001). Tahun 1994, Indonesian Biotechnology Consortium (IBC) terbentuk dengan tujuan aktif terlibat dalam pengembangan dan pemanfaatan bioteknologi secara bijak untuk kesejahteraan manusia dan konservasi lingkungan (Retnoningrum, 2005).

\section{Article History:}

Received: Juni, 28 $8^{\text {th }}$ 2019; Accepted: September, $29^{\text {th }} 2019$ ISSN: 2502-5325 (Online) Terakreditasi Peringkat 3 oleh Kementerian Riset, Teknologi dan Pendidikan Tinggi (ARJUNA) berdasarkan Keputusan Direktur Jenderal Penguatan Riset dan Pengembangan No: 23/E/KPT/2019 tanggal 8 Agustus 2019
Pada tahun 1988, perhatian terhadap bioteknologi semakin meningkat. Hal ini terbukti dengan peran pemerintah dalam memberikan bimbingan untuk perkembangan bioindustri dan adanya dukungan dari Research and Development (R \& D) (Sukara dan Loedin, 2014). Jaringan bioteknologi semakin berkembang hingga pada tahun 1999, Lembaga Eijkman bekerja sama dengan PT. Biofarma mengembangkan vaksin hepatitis B (Wahyono, 2001). Pada tahun 2013, Indonesia (Kementerian Riset dan Teknologi) bekerja sama dengan Jerman dalam rangka mengembangkan bioteknologi pembuatan obat (LIPI, 2013). Kemudian pada tahun 2018, Indonesia menjadi Centre of Excellence pengembangan vaksin dan produk bioteknologi negara-negara yang tergabung dalam OKI (Organisasi Kerjasama Islam) yang merupakan produsen vaksin di Negara Islam (Kementerian Kesehatan, 2018).

\section{Cite this as:}

Wasilah, U., Rohimah, S., Su'udi, M., (2019). Perkembangan Bioteknologi di Indonesia. Rekayasa, 12(2), 85-90. doi: https:// doi.org/10.21107/rekayasa.v12i2.5469

(c) 2019 Ummi Wasilah, Siti Rohimah, Mukhamad Su'udi 


\section{Peran Pemerintah}

Pemerintah secara konsisten menyediakan dana hibah untuk penelitian termasuk dalam bidang bioteknologi. Melalui program ini kualitas dan kuantitas dari penelitian menjadi meningkat. Pemerintah juga menyediakan dana untuk penelitian bagi staf pengajar di Universitas seperti Hibah Bersaing, Program Pembinaan Riset and Program University Research for Graduate Education (URGE) (Sukara dan Loadin, 2004). Selain itu, bioteknologi telah dikembangkan oleh berbagai lembaga penelitian dan universitas yang ada di Indonesia.

Perkembangan bioteknologi tidak terlepas dari peran pemerintah sebagai penyedia dana penelitian untuk meningkatkan pengetahuan, kualitas dan kemajuan bioteknologi di Indonesia. Sumber dana untuk penelitian di Indonesia selain dari pemerintah, pihak swasta atau lembaga-lembaga donor nasional maupun internasional dan individu juga berperan dalam pengembangan bioteknologi di Indonesia (Tabel 1). Pada tahun 1995, pemerintah menyediakan dana sebesar 500 milyar untuk penelitian termasuk dalam bidang bioteknologi kesehatan, pertanian dan industri (Komen dan Persley, 1994).

Selain dukungan dana, pemerintah juga berperan dalam memberikan kebijakan yang berkaitan dengan bioteknologi. Namun, kebijakan tersebut terkesan memperpanjang proses administrasi yang harus dilalui. Sebagai contoh di bidang biotek tanaman, moratorium yang diharuskan oleh pemerintah pada uji coba lapangan dan budidaya tanaman rekayasa genetika telah menghambat investasi di bidang bioteknologi (Pabendon, 2013). Kebijakan pemerintah dalam rangka pengembangan produk bioteknologi yang layak dikonsumsi harus melalui prosedur yang panjang. Prosedur ini meliputi (1) permohonan izin pemanfaatan tanaman transgenik, (2) permintaan saran teknik tentang pemanfaatan tanaman transgenik, (3) permintaan pengkajian kelayakan teknis pemanfaatan tanaman transgenik, (4) pemberian saran tentang kelayakan teknis pemanfaatan tanaman transgenik, (5) pemberian rekomendasi tentang usulan pemanfaatan tanaman transgenik, (6) permohonan izin pelepasan varietas tanaman, (7) persetujuan/penolakan usulan pemanfaatan tanaman transgenik, (8) persetu- juan/penolakan pelepasan varietas tanaman (Herman, 1999).

Pemerintah Indonesia telah mengupayakan keterjaminan Genetically Modified Organism (GMO) atau Produk Rekayasa Genetika (PRG) melalui pembentukan perangkat regulasi yaitu peraturan perundang-undangan terkait produk rekayasa genetika. Perangkat regulasi ini memiliki tujuan utama yaitu menjamin pemanfaatan produk rekayasa genetika yang aman untuk konsumsi masyarakat. Pengembangan tanaman produk rekayasa genetika di Indonesia masih memerlukan dukungan kebijakan pengembangan tanaman produk rekayasa genetika, kebijakan penelitian dan pengembangan terutama sumber daya manusia dan fasilitas, kebijakan bagi advokasi, sosialisasi, penyusunan pedoman pengembangan regulasi produk rekayasa genetika dan koordinasi, kelembagaan terkait serta dukungan kebijakan terhadap kajian dampak pengembangan tanaman produk rekayasa genetika dan regulasi (Estianti dan Herman, 2015).

\section{Status bioteknologi di Indonesia saat ini}

Perkembangan bioteknologi di Indonesia masih tergolong dalam kategori tertinggal jika dibandingkan dengan negara lain. Minimnya dana penelitian menjadi fakor penyebab ketertinggalan Indonesia dalam mengembangkan bioteknologi. Anggaran riset Indonesia merupakan anggaran terendah di Asia tenggara yaitu $0.2 \%$ atau 17 triliun, sedangkan Singapura dan Thailand telah menganggarkan dana riset sebesar $2.5 \%$, sementara Malaysia menganggarkan 1.8\% (LIPI, 2016). Dana riset sendiri 76\% bersumber dari anggaran APBN dan sisanya dari pihak swasta. Berbeda halnya dengan negara Asia yang lain seperti Singapura yang $80 \%$ dana riset berasal dari pihak swasta atau industri sedangkan Korea selatan hanya sekitar $16 \%$ dana yang berasal dari pemerintah dan sisanya dari pihak swasta dan industri (Antara News, 2019).

Keterlambatan perkembangan bioteknologi telah dibahas dalam Seminar Nasional Bioteknologi III UGM, dan dalam kesempatan tersebut Prof. Dr. Ir. Siti Subandiyah, M.Agr.Sc selaku ketua Pusat Studi Bioteknologi UGM menyatakan bahwa perkembangan bioteknologi di dunia internasional telah menggunakan teknologi modern

Tabel 1. Daftar lembaga pemerintah maupun swasta yang berkecimpung dalam bioteknologi

\begin{tabular}{cc}
\hline Nama & Lokasi \\
\hline Pusat Penelitian Bioteknologi LIPI & Bogor \\
Pusat Penelitian Bioteknologi ITB & Bandung \\
PAU Bioteknologi IPB & Bogor \\
PAU Bioteknologi UGM & Yogyakarta \\
BPPT & Jakarta \\
Balitbio & Bogor \\
Balitvet & Bogor
\end{tabular}


sedangkan perkembangannya di Indonesia memprihatinkan karena keterbatasan fasilitas dan bahan-bahan yang masih harus diimpor (UGM, 2015). Selain dana dan fasilitas, keterlambatan perkembangan bioteknologi juga diakibatkan oleh adanya kontroversi di bidang agama, budaya dan etnis (Mahrus, 2014).

Indonesia merupakan negara yang telah memanfaatkan produk bioteknologi terutama produk makanan dan obat-obatan. Pemanfaatan produk rekayasa di Indonesia telah diatur dan harus memenuhi peraturan perundang-undangan yang berlaku. Terdapat 7 peraturan perundang-undangan yang mengatur tentang perdagangan produk rekayasa genetika yaitu (1) UU No. 7/1996 tentang pangan, (2) UU No. 21/2004 tentang Cartagena Protocol on Biosafety to the Convention on Biological Diversity (Protokol Cartagena tentang Keamanan Hayati atas Konvensi Keanekaragaman Hayati), (3) PP No. 69/1999 tentang Label dan Iklan Pangan, (4) PP No. 28/2004 tentang Keamanan, Mutu dan Gizi Pangan, (5) PP No. 21/2005 tentang Keamanan Hayati Produk Rekayasa Genetika, (6) SKB 4 Menteri Th. 1999, (7) Peraturan Kepala Badan POM RI Nomor: HK. 00.05.23.3541 Tahun 2008 tentang Pedoman Pengkajian Keamanan Pangan Produk Rekayasa Genetik (Abbas, 1999). Masyarakat muslim yang merupakan mayoritas di Indonesia tentu memerlukan pelabelan halal bagi produk rekayasa genetika yang dikeluarkan oleh Majelis Ulama Indinesia (MUI) sehingga tidak menimbulkan keresahan bagi masyarakat untuk mengkonsumsinya.

Negara berkembang seperti Indonesia masih dibatasi oleh sumber daya manusia, sumber daya keuangan, rendahnya investasi $R \& D$, infrastruktur dan regulasi industri dan pasar (Pabendon, 2013). Hal ini merupakan penyebab yang selalu menjadi daftar panjang permasalahan yang dapat menghambat terealisasinya kemajuan bioteknologi. Sektor swasta sangat terbatas yang terlibat dalam pendanaan penelitian di bidang ini dikarenakan investasi yang terlalu tinggi.

\section{Bioteknlogi di bidang pertanian}

Penelitian bioteknologi pertanian mulai digalakkan dengan pembentukan Panitia Nasional Bioteknologi di bawah Menteri Negara Riset dan Teknologi pada tahun 1985. Kegiatan penelitian bioteknologi pertanian mulai terasa meningkat dengan dilaksanakannya program Riset Unggulan Terpadu (RUT) yang dikelola oleh Dewan Riset Nasional dan Hibah Bersaing yang dilaksanakan perguruan tinggi, yang memungkinkan kegiatan penelitian lebih dari satu tahun dengan dana yang berkesinambungan (Sunarlim dan Sutrisno, 2003). Lembaga-lembaga swasta dan pemerintah turut berperan dalam melakukan penelitian di bidang bioteknologi pertanian (Tabel 2).

Penelitian pengembangan bioteknologi dalam bidang pertanian dilakukan untuk merakit varietas unggul seperti tanaman padi dan tanaman semusim yang sangat membantu dalam menyediakan kebutuhan pangan di Indonesia. Meskipun bidang bioteknologi mulai berkembang, masih terdapat adanya penolakan terhadap produk-produk yang sudah dihasilkan. Menurut Andoko (2018) masalah yang dihadapi oleh negara berkembang seperti Indonesia adalah masalah sosial dan tantangan dalam pemasaran produk rekayasa genetika yang mana produsen harus melakukan pengujian lapang yang membutuhkan waktu lama dan biaya yang besar sehingga proses penerapan produk rekayasa genetika menjadi lama.

Penolakan terhadap produk rekayasa genetika juga diakibatkan oleh kekhawatiran masyarakat terhadap lingkungan, kesehatan, agama dan etika. Pada dasarnya produk rekayasa genetika merupakan hasil dari pemindahan gen yang diinginkan melalui teknik DNA rekombinan. Materi genetik yang baru belum tentu berhasil dipindahkan ke sel target sehingga memungkinkan dapat mengaktifkan, merubah atau menonaktifkan gen-gen yang ada didekat dari sel target. Hal ini dapat menyebabkan mutasi yang mengakibatkan beracun atau tidak layak konsumsi (Phillips, 1994). Di samping itu, munculnya virus baru pada tanaman transgenik sangat dimungkinkan terjadi sebagai proses pertahanan tanaman (Kamle et al., 2011). Adanya produk rekayasa genetika dapat mengancam keanekaragaman hayati dan timbulnya alergi dari produk rekayasa genetika (Coleman, 1996; Koch, 1998).

Namun demikian, perkembangan bioteknologi dalam bidang pertanian memiliki potensi yang menguntungkan. Menurut Sharma et al. (2002), rekayasa genetika membuka peluang yang luas bagi pemulia untuk mengakses gen dan trait baru dari sumber yang eksotik dan beragam untuk dimasukkan ke dalam varietas/hibrida unggul. Tujuan utama dari perakitan produk rekayasa genetika adalah untuk mengatasi berbagai permasalahan pangan yang dihadapi di berbagai belahan dunia karena pertumbuhan penduduk yang semakin pesat, termasuk Indonesia (Azadi dan Peter, 2010). Produk rekayasa genetika bermanfaat untuk mengurangi penggunaan pestisida kimia, menghasilkan makanan yang lebih bergizi serta obat-obatan.

\section{Bioteknologi dalam bidang kesehatan}

Bioteknologi dalam bidang kesehatan memberikan kesempatan dalam pemecahan masalah yaitu mendiagnosa, mencegah, serta mengobati berbagai penyakit termasuk penyakit genetis. Penerapan antibodi monoklonal dapat membantu mendiagnosa suatu penyakit (Prentis, 1984). Widyastuti (2017) melaporkan bahwa perkembangan bioteknologi di bidang kesehatan yaitu terapi gen yang dapat digunakan untuk penanganan penyakit baik bersifat genetis ataupun bukan. Terapi 
Tabel 2. Lembaga-lembaga swasta dan pemerintah yang turut berperan dalam melakukan penelitian di bidang bioteknologi pertanian

\begin{tabular}{ccc}
\hline Nama & Status & Bidang Penelitian \\
\hline BPPT & Pemerintah & Tanaman, ternak, hutan \\
P3B LIPI & Pemerintah & Tanaman, ternak, hutan \\
Balitbio & Pemerintah & Tanaman \\
Balitvet & Pemerintah & Veteriner \\
Unit Penelitian Bioteknologi Perkebunan & Pemerintah & Tanaman \\
Balai Penelitian Tembakau dan Tanaman & Pemerintah & Tanaman \\
Serat & Swasta & Tanaman \\
PT. Fitotek Unggul & Swasta & Tanaman \\
PT. Intidaya Agrolestari-Inagro & Swasta & Tanaman, industri \\
PT. Foodtech Utama International & Swasta & Hutan \\
PT. Indah Kilat & &
\end{tabular}

Sumber: Moeljopawiro dan Falconi (1999)

gen merupakan teknologi yang memungkinkan gengen yang rusak dapat diganti dengan gen-gen normal menggunakan vektor untuk menyisipkan DNA ke dalam sel (Moeljoprawiro, 2005).

Salah satu aspek penting dalam pengembangan produk bioteknologi kesehatan adalah pembuatan hormon manusia. Sebelum era bioteknologi, insulin diperoleh dari hewan ternak seperti sapi dan babi. Namun, cara ini memiliki kelemahan yaitu memungkinkan timbulnya alergi dan hasil produksi insulin yang terbatas (Ambarwati dan Susianawati, 2006). Namun, dengan pendekatan bioteknologi, insulin dapat diperoleh dengan cara memproduksi di mikroorganisme (Escherichia coli). Proses produksi insulin dapat melalui beberapa langkah, yaitu (1) masing-masing gen polipeptida alfa dan beta disintesis, (2) gen tersebut disisipkan pada submit $E$. coli yang mengandung promoter, operator dan gen structural yang mengkode $\beta$-galaktosidase, (3) gen alfa dan beta disisipkan ke dalam plasmid yang terpisah, (4) plasmid yang telah disisipi gen insulin dimasukan ke dalam sel E. coli, (5) insulin terbentuk dari proses ekspresi gen, (6) protein (insulin dimurnikan dan dipotong sehingga terpisah dengan protein $\beta$-galaktosidase), (7) diperoleh polipeptida alfa dan beta insulin kemudian polipeptida alfa diikatkan dengan polipeptida beta sehingga diperoleh insulin yang siap untuk digunakan (Sembiring et al., 1999).

Vaksin merupakan produk bioteknologi yang terus dikembangkan baik vaksin untuk manusia ataupun ternak. Vaksin merupakan bahan antigenik yang digunakan untuk kekebalan terhadap suatu penyakit yang biasanya mengandung virus atau mikroorganisme yang telah dimatikan atau dilemahkan (Melief et al., 2015). Pemberian vaksin (imunisasi) di Indonesia telah diselenggarakan pada tahun 1956 dan mengalami perkembangan serta perluasan pada tahun 1977 dalam rangka pencegahan penularan beberapa penyakit (Menteri Kesehatan, 2017).

\section{Bioteknologi di bidang lingkungan}

Bioteknologi lingkungan telah diterapkan di Indonesia sejak perkembangan industri dan urbanisasi yang telah mengganggu lingkungan yang awalnya bersih. Perkembangan bioteknologi dalam bidang lingkungan dapat merestorasi lingkungan yang tercemar serta meningkatkan kualitas lingkungan terutama bagi manusia. Untuk mengatasi permasalahan lingkungan, bioteknologi memanfaatkan mikroorganime dalam pengolahan limbah atau permasalahan lingkungan yang lain dikarenakan penggunaan mikroorganisme ini dinilai lebih alami dan tidak menimbulkan dampak yang berbahaya dibandingkan menggunakan bahan kimia atau sintetis (Susilowati, 2007).

Bioteknologi memiliki banyak manfaat bagi lingkungan diantara sebagai bioremediasi, bioleaching yaitu pelepasan logam dari mineral atau sedimen, memproduksi pupuk hayati yang mudah didegradasi oleh lingkungan serta mengurangi limbah plastik dengan memproduksi bioplastik yang berasal dari gula, lemak, protein dan serat tanaman (Fahmideh et al., 2014). Pendekatan bioteknologi dengan memanfaatkan penggunaan bakteri Desulfotomaculum orientis ICBB1204 dapat menurunkan kandungan $\mathrm{Cr}$ pada air limbah industri hingga 92,7\% selama 30 hari (Santosa et al., 2008). Penggunaan bioplastik akan mengurangi permasalahan lingkungan yang mana sampah plastik saat ini menjadi permasalahan di seluruh dunia. Bioplastik adalah plastik yang dapat digunakan seperti layaknya plastik pada umumnya namun ketika dibuang ke tanah akan mudah didekomposisi oleh mikroorganisme tanah dan akan menghasilkan senyawa asalnya yaitu air dan karbon dioksida (Yuniarti et al., 2014). Bioleaching merupakan aplikasi dari bioteknologi lingkungan yang memanfaatkan mikroorganisme dalam prosesnya. Bioleaching di Indonesia diterapkan untuk mengekstraksi emas, pyrate, tembaga dan besi. Penicillium chrysogenum dapat dimanfaatkan untuk mengekstraksi logam nikel dan menghasilkan 12,87\% sedangkan Aspergillus niger menghasilkan 11,83\% (Kurniawan et al., 2018). Penelitian lain melaporkan bahwa bakteri mixotrop dapat mengekstraksi nikel sebesar 34,3\% menggunakan substrat organik air lindi dengan penambahan belerang 20\% setelah proses berlangsung selama 28 hari (Mubarok et al., 2016). 


\section{SIMPULAN}

Bioteknologi memiliki banyak manfaat untuk kemajuan dalam bidang pertanian, kesehatan maupun lingkungan. Namun, bioteknologi di Indonesia belum berkembang pesat dibandingkan dengan negara Asia yang lain. Beberapa faktor yang mempengaruhi keterlambatan perkembangan bioteknologi ini meliputi dana penelitian yang rendah, sumberdaya manusia dan kurangnya fasilitas. Faktor lain seperti budaya dan agama juga mempengaruhi perkembangan bioteknologi di Indonesia.

\section{DAFTAR PUSTAKA}

Abbas, N. (2009). Perkembangan Teknologi di Bidang Produksi Pangan Dan Obat - Obatan Serta Hak - Hak Konsumen. Jurnal Hukum. Vol. 3 No. 16, 423-438.

Ambarwati \& Susianawati, N. (2006). Kemajuan IPTEK untuk Kemaslahatan Umat. SUHUF. Vol. 18 No. 2, 156-165.

Andoko, E. (2018). The Controversial Case Study: Genetically Modified Food in Indonesia. FFTC Agricultural Policy Articles.

Antara News. (2019). Menristek Menjawab mengapa dana riset Indonesia rendah.https//m.antaranews.com/berita/800767//menristek-menjawab-mengapa-dana-riset-indonesia-rendah [diakses 6 Juni 2019].

Azadi, H. \& Peter, H. (2010). Genetically Modified and Organic Crop in Developing Countries: A Review of Option for Food Security. Biotechnology Advances, 28, 160-168.

Coleman, A. (1996). Production Of Proteins in The Milk of Transgenic Livestock: Problems, Solution And Success. Am J Clin Nutr, 63, 5639-5645.

Estianti, A. \& Herman, M. (2015). Regulasi Keamanan Hayati Produk Rekayasa Genetik di Indonesia. Analisis Kebijakan Pertanian, Vol 13 No. 2, 129-146.

Fahmideh, L., Khodadadi, E., \& Khodadadi, E. (2014). A Review of Applications of Biotechnology in the Environment. International Journal of Farming and Allied Science, Vol. 3 No. 12, 1319-1325.

Herman, M. (1999). Tanaman Hasil Rekayasa Genetik dan Pengaturan Keamanannya di Indonesia. Buletin AgroBio. Vol. 3 No.1, 8-26.

Kamle, S., Kumar, A., \& Bhatnagar, R. K. (2011). Development of Multiplex and Construct Spesific PCR Assay for Detection of cry2Ab Transgene in Genetically Modified Crops And Product. GM Crops. Vol. 2 No. 1, 74-81.
Kementerian Kesehatan RI. (2018). Indonesia Jadi Center of Excelent: Momentum Baru Bagi Negara-Negara Islam Dalam Pengembangan Vaksin dan Produk Bioteknologi. www.depkes.go.id/article/ view/18051500002/indonesia-jadi-center-of-excelent-momentum-baru-bagi-negera-negara-islam-dalam-pengembangan-vaksin-d.html.

Koch, K. (1998). Food Safety Battle: Organic vs Biotech. Congressional Quarterly Researcher. Vol. 9 No. 33, 761-784.

Komen, I. \& Parsley. (1994). A Comparison of Goverment Programs. Agricultural Biotechnology in Developing Countries, A Cross Country Review, ISNAR, Netherland.

Kurniawan, R., Juhanda, S., Gustinah, H. M., \& Pratami, A. P. Prosiding Seminar Nasional Teknik Kimia "Kejuangan" Pengembangan Teknologi Kimia Untuk Pengolahan Sumber Daya Alam Indonesia.

LIPI. (2016). Anggaran Riset Indonesia Terendah di Asia Tenggara. http://Lipi.go.id/Lipimedia/anggaran-riset-indonesia-terendah-di-asia-tenggara/16281 [Diakses 8 Juni 2019].

LIPI. (2013). Indonesia Jerman Kembangkan Kerjasama Bioteknologi Pembuatan Obat. http://lipi. go.id/berita/single/indonesia/Jerman-kembangkan-kerjasama--bioteknologi-pembuatan-obat/8542.

Mahrus. (2014). Kontroversi Produk Rekayasa Genetika Yang Dikonsumsi Masyarakat. Jurnal Biologi Tropis. Vol. 14 No. 2, 108-119.

Menteri Kesehatan RI. (2017). Peraturan Menteri Kesehatan Republik Indonesia Nomor 12 Tahun 2017 tentang Penyelenggaraan Imunisasi.

Melief, C. J. M., Hall, T. V., Arens, R., Ossendorv, F., Van Der Burg, S. H. (2015). Therapeutic cancer, Faccines. J Clin invest. Vol. 125 No. 9, 3401-3412.

Moeljopawiro, S. \& Falconi, C. (1999). Agriculture Bioteknologi Research Indicators: Indonesia. Discussion Paper No. 99-07 April 1999. ISNAR, The Netherlands.

Mubarok, M. Z., Pratama, B. E., \& Chaerun, S. K. 2016. Bioleaching Nikel dari Bijih Limonit Pulau Gag Menggunakan Bakteri Mixotrof. Jurnal Teknologi Mineral dan Batubara. Vol. 12 No. 1, 69-79.

Muelyoprawiro, S. (2005). Perang Biologi dalam Kesehatan. Seminar Nasional dan Konggres Biologi XIII. Yogyakarta: UGM.

Pabendon, M. B. (2013). Peran Penelitian Bioteknologi Menunjang Pertanian Bioindustri. Seminar Nasional Serealia. 
Phillips, S. C. (1994). Genetically Engineered Foods: Do They Pose Health and Environmental Hazard. CQ Researcher. Vol. 4 No. 29.

Prentis, S. (1984). Biotechnology, A New Industrial revolution. London: Orbis Pulishing.

Retnoningrum, D. S., Kardena, E., \& Noer. A. S. (2005) Indonesia Biotechnology Consortium: Present and Future. Workshop on the Establishment of Biotechnology Information Network Asia (BINASIA) Nodal in Indonesia. July 27-28, Jakarta.

Santosa, D. A., Kurniawan, T., \& Lina, F. D. (2008). Bioteknologi Lingkungan Untuk Penanggulangan Limbah Mengandung Krom. Jurnal Tanah dan Lingkungan. Vol. 1 No. 2.

Sembiring, L., Nastiti, S. J., \& Suharni, T. T. (1999). Mikro biologi umum. Yogyakarta: UGM.

Sunarlim, N. \& Sutrisno. (2003). Perkembangan Penelitian Bioteknologi Pertanian di Indonesia. Buletin Agrobio. Vol. 6 No. 1, 1-7.

Sukara, E \& Loadin, S. (2004). Agricultural Biotechnology in Indonesia. R \& D Center for Biotechnology, The Indonesian Institute of Sciences (LIPI), Bogor, Indonesia.
Sharma, H. C., Crouch, J. H., Sharma, K. Seetharama, K. N. \& Hash, C.T. (2002). Applications of Biotechnology for Crop Improvement: Prospects and Constraints. Plant Science 163, 381-395.

Schmid, R. D., Chung, B., Jones, A. J., Saono, S., Scriven, J., \& Tsai, J. H. J. (1995). Biotechnology in the Asian-Pacific Region. VCH, Weinheim, Germany.

Susilowati, R. (2001). Bioteknologi Sebagai Penunjang Pertanian Berkelanjutan. Jurnal Bestari. Vol. 31.

UGM. (2015). Perkembangan Bioteknologi di Indonesia Memprihatinkan. https://ugm.ac.id/id/berita/10614- perkembangan- bioteknologi- di- indonesia- memprihatinkan [diakses 8 Juni 2019]

Wahyono, P. (2001). Bioteknologi, Sebuah Ilmu Masa Depan yang Menjanjikan. http://ejournal.umm. ac.id/index.php/bestari/article/view/3167.

Widyastuti, D. A. (2017). Terapi Gen: Dari Bioteknologi Untuk Kesehatan. Al-Kauniyah. Journal of Biology. Vol. 10 No. 1, 60-72.

Yuniarti, L. I., Hutomo, G. S., \& Rahim, A. (2014). Sintesis dan Karatrerisasi Bioplastik berbasis Pati Sagu (Metroxylon sp.) e-J Agrotekbis. Vol. 2 No. 1, 3846. 